Original research paper

\title{
Absorption of Phenol Red and Bromphenol Blue as Model Drugs from Peritoneal Cavity around Liver Surface in Rats
}

KOYO NISHIDA, HIROAKI AMAGISHI, HITOSHI SASAKI AND JUNZO

NAKAMURA

School of Pharmaceutical Sciences, Nagasaki University, 1-14 Bunkyo-machi, Nagasaki 852, Japan

Shortened Title: PERITONEAL ABSORPTION FROM LIVER SURFACE

Correspondence: K. Nishida, School of Pharmaceutical Sciences, Nagasaki University, 1-14 Bunkyo-machi, Nagasaki 852, Japan. 


\begin{abstract}
The effect of the injection site on the pharmacokinetics of phenol red and bromphenol blue as model drugs after intraperitoneal (i.p.) administration into rats was examined. Their absorption rate from the peritoneal cavity was faster after i.p. administration to the liver surface (LS) than that after i.p. administration to the distal small intestine (SI), as shown by the increase in maximum concentration and decrease in mean residence time in plasma. A similar tendency was observed in the biliary excretion pattern. The enhanced absorption rate was supported by the significantly smaller amount of both drugs remaining in the peritoneal cavity at 15 min after LS administration than that after SI administration. The liver concentration of the model drugs at 15 min after LS administration was 1.5 - 2.0 times higher than that after SI administration. Accordingly, LS administration was shown to be effective with good absorbability and efficient drug delivery to the liver.
\end{abstract}


In the chemotherapy of a localized tumor in the liver, direct drug injection to the liver has been suggested to enhance local drug distribution (Mattijssen et al 1992; Dubinett et al 1993; Balemans et al 1993). On the other hand, regional drug application to the organ surface via the intraperitoneal (i.p.) route may be advantageous for organ-specific drug delivery, particularly to the liver. However, the differences in the drug absorption from the peritoneal cavity with the injection site have not been elucidated fully. In the present study, we examined the effects of i.p. injection site on absorption of two organic anions (phenol red and bromphenol blue) as model drugs. 


\section{Materials and Methods}

\section{Chemicals}

Phenol red and bromphenol blue were purchased from Nacalai Tesque, Inc. (Kyoto, Japan). All other chemicals were of reagent grade.

In-vivo experiment

All animal procedures in the present study conformed to the Guideline for Animal Experimentation in Nagasaki University.

Male Wistar rats, 230-250 g, were anaesthetized with sodium pentobarbitone (50 mg $\mathrm{kg}^{-1}$, i.m.), and the left femoral artery was cannulated with a polyethylene tube (i.d. $0.5 \mathrm{~mm}$, o.d. $0.8 \mathrm{~mm}$, Dural Plastics, Dural, Australia). An incision of approximately $2 \mathrm{~cm}$ was made in the middle abdomen and the common bile duct was cannulated with a polyethylene tube (i.d. 0.28 mm, o.d. 0.61 mm, Becton Dickinson \& Co., Parsippany, NJ, U.S.A.). Phenol red (2 or $6 \mathrm{mg}$ ) or bromphenol blue (2 mg) in an isotonic phosphate buffer (pH 7.4) (0.2 mL) was administered i.p. to the area of either the liver surface (LS) or distal small intestine (SI). The injection point of LS administration was the division between the right and left lobe. The drug solution was i.p. administered to SI, $5 \mathrm{~cm}$ below the injection point of LS.

After application of the drug solution, $200 \mu \mathrm{L}$ blood was collected at selected times from the heparinized cannula inserted into the femoral artery over $4 \mathrm{~h}$. Blood was centrifuged at $15000 \mathrm{rev}^{-1} \mathrm{~min}^{-1}$ for $5 \mathrm{~min}$. Bile samples were collected at appropriate time intervals for $4 \mathrm{~h}$. In another experiments, the drug solution remaining in the peritoneal cavity was withdrawn by washing with saline at 15 or 60 min after dosing, and then the liver was excised.

Analytical method 
The concentrations of model drugs in plasma, bile and remaining solution in the peritoneal cavity were determined.

The concentration of free phenol red was determined spectrophotometrically at $560 \mathrm{~nm}$ after dilution with $1 \mathrm{M} \mathrm{NaOH}$. The total concentration of free phenol red and its metabolite was measured in the same manner after the samples were subjected to acid hydrolysis (1 $\mathrm{M} \mathrm{HCl}$ at $100^{\circ} \mathrm{C}$ for $30 \mathrm{~min}$ ) (Hart \& Schanker 1966). The concentration of phenol red metabolite was estimated from the difference between these values.

The concentration of bromphenol blue was determined spectrophotometrically at 591 nm after dilution with isotonic phosphate buffer (pH 7.4) (Takada et al 1974).

The concentration of the model drug in the liver was determined as follows. The excised liver was homogenized in threefold of its weight of distilled water and of pH 6.5 phosphate buffer for analysis of phenol red and bromphenol blue, respectively. After 5 $\mathrm{mL}$ of acetone was added to $5 \mathrm{~mL}$ of the liver homogenate, the mixture was shaken for 15 min, followed by centrifugation for $15 \mathrm{~min}$ at $3000 \mathrm{rev}^{-1} \mathrm{~min}^{-1}$. The concentration of the drug in the resulting supernatant was determined in the same manner as described above.

\section{Calculation of moment parameters}

The moment parameters for the plasma concentration profile of free phenol red and bromphenol blue ( $\mathrm{AUC}_{\mathrm{p}}, \mathrm{MRT}_{\mathrm{p}}$ ) and those for biliary excretion rate-time curves of free phenol red and bromphenol blue $\left(\mathrm{AUC}_{\mathrm{b}, \mathrm{f}}, \mathrm{MRT}_{\mathrm{b}, \mathrm{f}}\right)$, and of the phenol red metabolite $\left(\mathrm{AUC}_{\mathrm{b}, \mathrm{m}}, \mathrm{MRT}_{\mathrm{b}, \mathrm{m}}\right)$ were calculated by numeral integration using a linear trapezoidal formula and extrapolation to infinite time based on a monoexponential equation (Yamaoka et al., 1978).

\section{Results and Discussion}


I.p. administration has been extensively applied to treatment of the cancer restricted to the peritoneal cavity such as ovarian carcinoma, and is considered to be an effective method for organ-specific drug delivery, owing to ease of regional delivery of a drug to the target site.

The main purpose of this study is to examine the difference in pharmacokinetics after i.p. administration of the drug by the injection site. We selected phenol red and bromphenol blue as model drugs, because their in-vivo absorbability after application to rat liver surface employing a glass cell were previously determined (Nishida et al 1994, 1995).

$<$ Fig. $1>$

Figs $1 \mathrm{a}$ and $1 \mathrm{~b}$ show the plasma concentration profiles of phenol red (2 or $6 \mathrm{mg}$ ) and bromphenol blue (2 mg), respectively, after their i.p. administration to the area around the LS or SI in rats. $\quad$ I.p. administered phenol red appeared in the plasma with a peak level during 30 min after dosing, followed by gradual disappearance. The plasma concentration of phenol red after LS administration was higher than that after SI administration up to $60 \mathrm{~min}$, and its maximum concentration $\left(\mathrm{C}_{\max }\right)$ was increased. On the other hand, the plasma concentration profile of bromphenol blue after LS administration reached a peak at 5 min. $\quad$ In this case, the $C_{\max }$ value after LS administration was 3.3 times that after SI administration. These findings suggest the increased absorption from the peritoneal cavity around the LS in rats.

$<$ Fig. $2>$

Figs 2a-c illustrate the biliary excretion rate-time curves of free phenol red and its metabolite, and bromphenol blue after LS or SI administration of phenol red and bromphenol blue. During the first 60 min after LS administration, the biliary excretion of both drugs was more rapid than that after SI administration. This observation can be explained by the increased peritoneal absorption rate.

$<$ Table $1>$ 
The overall absorption process can be evaluated with moment parameters. In particular, $\mathrm{AUC}_{\mathrm{p}}$ and $\mathrm{MRT}_{\mathrm{p}}$ are useful parameters for roughly evaluating the drug absorbability from the peritoneal cavity. Table 1 summarizes the moment parameters for phenol red and bromphenol blue after LS or SI administration into rats.

The $\mathrm{AUC}_{\mathrm{p}}$ values for both drugs after LS administration were larger than those after SI administration, although less markedly for phenol red. The difference of $\mathrm{MRT}_{\mathrm{p}}$ values between i.p. and i.v. administration corresponds to the mean time value for the absorption from the peritoneal cavity (MAT). $\quad$ MRT $_{\mathrm{p}}$ after i.v. administration of phenol red at a dose of 2 or $6 \mathrm{mg}$, and bromphenol blue were calculated to be 43.7, 43.6 and $9.5 \mathrm{~min}$, respectively (our unpublished data). As shown in Table 1, the MAT values for both drugs were shortened considerably by LS administration, the reduction being marked for bromphenol blue.

With respect to biliary excretion, the $\mathrm{MRT}_{\mathrm{b}, \mathrm{f}}$ for both drugs after LS administration was shorter than that after SI administration. The $\mathrm{AUC}_{\mathrm{b}, \mathrm{m}}$ value for phenol red was increased by LS administration, suggesting that its metabolism is affected by the injection site.

$<$ Table 2>

Table 2 shows the level of phenol red and bromphenol blue in the peritoneal cavity and liver at 15 and 60 min after LS or SI administration

The amount remaining in the peritoneal cavity after LS administration was smaller than that after SI administration for both drugs, although the difference was not significant for bromphenol blue at 60 min. This supports the high absorption of these model drugs from the peritoneal cavity around the LS.

The liver concentrations of phenol red and bromphenol blue at 15 min after LS administration were 1.5 - 2.0 times higher than those after SI administration, which suggests that LS administration enhances drug delivery to the liver. 
The effects of molecular weight (Dedrick et al 1978; Litterst et al 1982), charge (Lukas et al 1971), and injection volume (Barrett et al 1991; Bredberg et al 1994) on the drug absorption after i.p. administration have been reported. In contrast, the present study provides the evidence of a difference in pharmacokinetics after i.p. administration with the injection site. However, the mechanism underlying this phenomenon is not clear.

Previously (Nishida et al 1994, 1995), we examined the in-vivo behaviour of model drugs after application to LS in rats, using a cylindrical glass cell (i.d. $9 \mathrm{~mm}$; area $0.64 \mathrm{~cm}^{2}$ ), to clarify drug absorption from the liver-surface membrane. The absorption rates of phenol red and bromphenol blue at $6 \mathrm{~h}$ were relatively high (91.8 and $71.6 \%$ of dose, respectively). The difference in the peritoneal absorption of model drugs with the injection site might be closely related to the good absorbability from the liver-surface membrane.

\section{Acknowledgements}

We wish to thank Yuki Masunaga, Masayuki Kobayashi and Ayako Nagase for skilled technical assistance. This work was supported by a Grant-in-Aid for Scientific Research from the Ministry of Education, Science and Culture, Japan. 


\section{References}

Balemans, L. T. M., Mattijssen, V., Steerenberg, P. A., Van Driel, B. E. M., De Mulder, P. H. M., Den Otter, W. (1993) Locoregional therapy with polyethylene-glycol-modified interleukin-2 of an intradermally growing hapatocellular carcinoma in the guinea pig induces T-cell-mediated antitumor activity. Cancer Immunol. Immunother. 37: 7-14

Barrett, J. S., Wagner, J. G., Fisher, S. J., Wahl, R. L. (1991) Effect of intraperitoneal injection volume and antibody protein dose on the pharmacokinetics of intraperitoneally administered IgG2ak murine monoclonal antibody in the rat. Cancer Res. 51: 3434-3444

Bredberg, E., Lennernäs, H., Paalzow, L. (1994) Pharmacokinetics of levodopa and carbidopa in rats following different routes of administration. Pharm. Res. 11: 549-555

Dedrick, R. L., Myers, C. E., Bungay, P. M., De Vita, V. T. (1978) Pharmacokinetic rationale for peritoneal drug administration in the treatment of ovarian cancer. Cancer Treat. Rep. 62: 1-11

Dubinett, S. M., Patrone, L., Tobias, J., Cochran, A. J., Wen, D.R., McBride, W. H. (1993) Intratumoral interleukin-2 immunotherapy: activation of tumor-infiltrating and splenic lymphocytes in vivo. Cancer Immunol. Immunother. 36: 156-162

Hart, L. G., Schanker, L. S. (1966) The chemical forms in which phenol red is secreted into bile of rats. Proc. Soc. Exp. Biol. Med. 123: 433-435

Litterst, C. L., Torres, I. J., Arnold, S., McGunagle, D., Furner, R., Sikic, B. I., Guarino, A. M. (1982) Absorption of antineoplastic drugs following large-volume ip administration to rats. Cancer Treat. Rep. 66: 147-155

Lukas, G., Brindle, S. D., Greengard, P. (1971) The route of absorption of intraperitoneally administered compounds. J. Pharmacol. Exp. Ther. 178: 562-566

Mattijssen, V., Balemans, L. T. M., Steerenberg, P. A., De Mulder, P. H. M. (1992) 
Polyethylene-glycol-modified interleukin-2 is superior to interleukin-2 in locoregional immunotherapy of established guinea-pig tumors. Int. J. Cancer 51: 812-817

Nishida, K., Sato, N., Sasaki, H., Nakamura, J. (1994) Absorption of organic anions as model drugs following application to rat liver surface in-vivo. J. Pharm. Pharmacol. 46: 867-870

Nishida, K., Sato, N., Sasaki, H., Nakamura, J. (1995) Mechanisms for drug absorption from rat liver surface membrane: Effect of dose and transport inhibitors on the pharmacokinetics of phenol red. J. Pharm. Pharmacol. in press (No. J94075)

Takada, K., Mizobuchi, Y., Muranishi, S. (1974) Biopharmaceutical study of the hepato-biliary transport of drugs. I. Hepato-biliary transport of non-metabolizing organic anionic compounds in rat. Chem. Pharm. Bull. 22: 922-929

Yamaoka, K., Nakagawa, T., Uno, T. (1978) Statistical moments in pharmacokinetics. J. Pharmacokinet. Biopharm. 6: 547-558 
Legends for figures

FIG. 1. Plasma concentration profiles of phenol red (a) at a dose of 2 (circle) or $6 \mathrm{mg}$ (triangle), and bromphenol blue (b) (dose: $2 \mathrm{mg}$ ) (circle) after LS (closed symbol) or SI (open symbol) administration. Values are means \pm s.e. of at least three experiments.

FIG. 2. Biliary excretion rate-time curves for free phenol red (circle) and its metabolite (triangle) at a dose of 2 (a) or $6 \mathrm{mg}$ (b), and bromphenol blue (c) (dose: $2 \mathrm{mg}$ ) (circle) after LS (closed symbol) or SI (open symbol) administration. Values are means \pm s.e. of at least three experiments. 
Table 1. Moment parameters for plasma concentration and biliary excretion rate-time curves for free phenol red and its metabolite, and bromphenol blue after LS or SI administration in rats.

\begin{tabular}{|c|c|c|c|c|c|c|}
\hline \multirow[b]{2}{*}{ Parameter } & \multicolumn{2}{|c|}{ Phenol red (2 mg) } & \multicolumn{4}{|c|}{ Phenol red $(6 \mathrm{mg})$ Bromphenol blue $(2 \mathrm{mg})$} \\
\hline & SI & LS & SI & LS & SI & LS \\
\hline $\begin{array}{l}\operatorname{AUC}_{p} \\
\left(\mu g \min \mathrm{mL}^{-1}\right)\end{array}$ & $\begin{array}{r}1443.9 \\
\pm 72.8\end{array}$ & $\begin{array}{r}1533.6 \\
\pm 53.4\end{array}$ & $\begin{array}{l}3255.5 \\
\pm 232.9\end{array}$ & $\begin{array}{l}3663.7 \\
\pm 306.1\end{array}$ & $\begin{array}{r}224.5 \\
\pm 8.3\end{array}$ & $\begin{array}{l}433.9^{\star} \\
\pm 61.6\end{array}$ \\
\hline $\mathrm{MRT}_{\mathrm{p}}(\min )$ & $\begin{array}{l}79.3 \\
\pm 0.8\end{array}$ & $\begin{array}{l}67.2^{\star \star} \\
\pm 2.2\end{array}$ & $\begin{array}{l}70.1 \\
\pm 5.5\end{array}$ & $\begin{array}{l}57.9 * \\
\pm 1.8\end{array}$ & $\begin{array}{l}61.3 \\
\pm 3.5\end{array}$ & $\begin{array}{l}25.9^{\star *} \\
\pm 1.7\end{array}$ \\
\hline $\mathrm{MAT}^{\mathrm{a}}(\mathrm{min})$ & 35.6 & 23.5 & 26.5 & 14.3 & 51.8 & 16.4 \\
\hline $\mathrm{AUC}_{\mathrm{b}, \mathrm{f}}(\mu \mathrm{g})$ & $\begin{array}{r}1037.8 \\
\pm 58.9\end{array}$ & $\begin{array}{l}1115.1 \\
\pm 108.0\end{array}$ & $\begin{array}{r}3283.3 \\
\pm 99.9\end{array}$ & $\begin{array}{l}3009.6 \\
\pm 173.4\end{array}$ & $\begin{array}{r}1566.1 \\
\pm 74.9\end{array}$ & $\begin{array}{r}1621.2 \\
\pm 71.1\end{array}$ \\
\hline$A \cup C_{b, m}(\mu g)$ & $\begin{array}{r}347.3 \\
\pm 160.5\end{array}$ & $\begin{array}{r}534.8 \\
\pm 179.0\end{array}$ & $\begin{array}{l}1143.1 \\
\pm 134.1\end{array}$ & $\begin{array}{r}1461.0 \\
\pm 72.7\end{array}$ & - & - \\
\hline $\mathrm{MRT}_{\mathrm{b}, \mathrm{f}}(\min )$ & $\begin{array}{r}131.8 \\
\pm 5.5\end{array}$ & $\begin{array}{c}112.6^{\star} \\
\pm 5.9\end{array}$ & $\begin{array}{r}109.5 \\
\pm 4.9\end{array}$ & $\begin{array}{l}88.6^{\star} \\
\pm 4.1\end{array}$ & $\begin{array}{r}214.9 \\
\pm 8.0\end{array}$ & $\begin{array}{l}192.5 \\
\pm 20.1\end{array}$ \\
\hline $\mathrm{MRT}_{\mathrm{b}, \mathrm{m}}(\min )$ & $\begin{array}{l}175.7 \\
\pm 16.7\end{array}$ & $\begin{array}{l}182.7 \\
\pm 29.9\end{array}$ & $\begin{array}{r}113.8 \\
\pm 5.5\end{array}$ & $\begin{array}{r}118.9 \\
\pm 8.4\end{array}$ & - & - \\
\hline
\end{tabular}

Statistical significance from SI by Student's $t$-test $\left({ }^{\star} P<0.05\right.$, $\left.{ }^{\star *} P<0.01\right)$. a MAT (mean absorption time) is the difference of MRT $_{p}$ values between i.v. and i.p. administration. Each value is the mean \pm s.e. of at least three experiments. 
Table 2. Recovery (\% of dose) in peritoneal cavity and concentration in liver of phenol red and bromphenol blue after LS or SI administration in rats.

\begin{tabular}{|c|c|c|c|c|c|}
\hline \multirow[b]{2}{*}{ Drug } & \multirow[b]{2}{*}{ Site } & \multicolumn{2}{|c|}{ Peritoneal cavity (\%) } & \multicolumn{2}{|c|}{ Liver ( $\mu \mathrm{g}$ g tissu $\mathrm{e}^{-1}$ ) } \\
\hline & & $15 \min$ & $60 \min$ & $15 \min$ & $60 \mathrm{~min}$ \\
\hline \multirow[t]{2}{*}{$\begin{array}{l}\text { Phenol red } \\
(2 \mathrm{mg})\end{array}$} & $\mathrm{SI}$ & $\begin{array}{r}57.9 \\
\pm 2.6\end{array}$ & $\begin{array}{r}27.2 \\
\pm 2.1\end{array}$ & $\begin{array}{r}4.1 \\
\pm 0.4\end{array}$ & $\begin{array}{r}4.7 \\
\pm 0.2\end{array}$ \\
\hline & LS & $\begin{array}{l}49.9^{\star} \\
\pm 2.4\end{array}$ & $\begin{array}{l}16.3^{\star} \\
\pm 2.5\end{array}$ & $\begin{array}{l}8.3^{\star *} \\
\pm 0.9\end{array}$ & $\begin{array}{l}10.6^{\star *} \\
\pm 0.8\end{array}$ \\
\hline \multirow[t]{2}{*}{$\begin{array}{l}\text { Phenol red } \\
(6 \mathrm{mg})\end{array}$} & $\mathrm{SI}$ & $\begin{array}{r}58.0 \\
\pm 2.4\end{array}$ & $\begin{array}{r}27.1 \\
\pm 1.1\end{array}$ & $\begin{array}{r}15.1 \\
\pm 0.8\end{array}$ & $\begin{array}{r}12.5 \\
\pm 2.2\end{array}$ \\
\hline & LS & $\begin{array}{l}43.6^{\star *} \\
\pm 2.4\end{array}$ & $\begin{array}{l}16.9 * * \\
\pm 1.1\end{array}$ & $\begin{array}{l}26.5^{\star \star} \\
\pm 0.2\end{array}$ & $\begin{array}{r}15.8 \\
\pm 0.8\end{array}$ \\
\hline \multirow[t]{2}{*}{$\begin{array}{l}\text { Bromphenol blue } \\
(2 \mathrm{mg})\end{array}$} & $\mathrm{SI}$ & $\begin{array}{r}63.0 \\
\pm 2.4\end{array}$ & $\begin{array}{r}36.7 \\
\pm 2.0\end{array}$ & $\begin{array}{r}22.0 \\
\pm 2.3\end{array}$ & $\begin{array}{r}31.2 \\
\pm 1.8\end{array}$ \\
\hline & LS & $\begin{array}{l}47.0^{\star \star} \\
\pm 2.3\end{array}$ & $\begin{array}{r}35.4 \\
\pm 1.9\end{array}$ & $\begin{array}{l}33.1^{\star \star} \\
\pm 1.6\end{array}$ & $\begin{array}{r}31.1 \\
\pm 1.8\end{array}$ \\
\hline
\end{tabular}

Statistical significance from SI by Student's $t$-test $\left({ }^{\star} P<0.05,{ }^{* \star} P<0.01\right)$. Each value is the mean \pm s.e. of at least three experiments. 